\title{
The Implementation of Scientific Approach Using Video in Improving Social Science Learning on The Theme of The Beauty of Diversity in My Country in Fourth Grade Students of SD Negeri 4 Kutosari in Academic Year 2018/2019
}

\author{
Musfik Wahyu Sofiyulloh ${ }^{1}$, M. Chamdani ${ }^{2}$ Joharman $^{3}$ \\ 1,2,3Universitas Sebelas Maret \\ musfik08@gmail.com
}

\section{Article History}

accepted 01/10/2019

\begin{abstract}
This study aimed: (1) to describe the steps on the implementation of scientific approach using video in improving social science learning, (2) to improve social science learning with the theme of the beauty of diversity in my country through the implementation of scientific approach using video in the fourth grade students of SD Negeri 4 Kutosari in Academic Year 2018/2019, and (3) to describe problems and solutions on the implementation of scientific approach using video in the fourth grade students of SD Negeri 4 Kutosari in Academic Year 2018/2019. This research is a collaborative classroom action research. Each cycle consists of planning, action, observation, and reflection. The subjects of the research were teacher and fourth grade students of SD Negeri 4 Kutosari. Techniques of collecting data were test and non-test. Validity of data in this research was analyzed using techniques of triangulation and sources. Data were analysed through data reduction, data display, and drawing conclusion. The result of this research indicated the implementation of scientific approach using video could improve social science learning with the theme of The Beauty of Diversity in My Country in fourth grade students of SD Negeri 4 Kutosari in academic year 2018/2019.
\end{abstract}

Keywords: scientific approach, video media, social science learning

\begin{abstract}
Abstrak
Penelitian ini bertujuan: (1) untuk mendeskripsikan langkah-langkah penerapan pendekatan ilmiah menggunakan video dalam meningkatkan pembelajaran ilmu sosial, (2) meningkatkan pembelajaran ilmu sosial dengan tema keindahan keanekaragaman di negara saya melalui penerapan pendekatan ilmiah menggunakan video pada siswa kelas empat SD Negeri 4 Kutosari pada Tahun Akademik 2018/2019, dan (3) untuk menggambarkan masalah dan solusi pada penerapan pendekatan ilmiah menggunakan video pada siswa kelas empat SD Negeri 4 Kutosari pada Tahun Akademik 2018 / 2019. Penelitian ini adalah penelitian tindakan kelas kolaboratif. Setiap siklus terdiri dari perencanaan, tindakan, observasi, dan refleksi. Subjek penelitian adalah guru dan siswa kelas IV SD Negeri 4 Kutosari. Teknik pengumpulan data adalah tes dan non-tes. Validitas data dalam penelitian ini dianalisis menggunakan teknik triangulasi dan sumber. Data dianalisis melalui reduksi data, tampilan data, dan penarikan kesimpulan. Hasil penelitian ini menunjukkan bahwa penerapan pendekatan saintifik menggunakan video dapat meningkatkan pembelajaran sains sosial dengan tema The Beauty of Diversity in My Country pada siswa kelas IV SD Negeri 4 Kutosari pada tahun akademik 2018/2019.
\end{abstract}

Kata kunci: pendekatan ilmiah, media video, pembelajaran ilmu sosial 


\section{PENDAHULUAN}

Pendidikan merupakan faktor penting bagi kelangsungan hidup bangsa. Suatu bangsa akan maju ketika bangsa tersebut memperhati-kan bagaimana sebuah sistem pen-didikan yang berlaku di negara tersebut. Melalui pendidikan, akan terbentuklah sebuah bangsa yang memiliki peradaban dan berkualitas dari segi sumber daya manusianya. Salah satu upaya untuk me-ningkatkan kualitas SDM melalui pendidikan diperlukan perbaikan terhadap sistem pendidikan terutama kompetensi yang mendukung tugas seorang guru sebagai pendidik. Sagala (2013: 61) mengemukakan bahwa indikator kesuksesan proses pembelajaran terletak pada kesiapan guru dalam mengenal karakteristik siswa.

Salah satu mata pelajaran yang yang diatur dalam Peraturan Menteri Pendidikan Nasional (Permendiknas) yaitu IImu Penge-tahuan Sosial (IPS). IImu Penge-tahuan Sosial (IPS) merupakan salah satu mata pelajaran yang diberikan mulai dari SD/MI. Susanto (2014: 6) berpendapat bahwa ilmu peng-etahuan sosial adalah perpaduan berbagai ilmu sosial dan humaniora yang di dalamnya meliputi ekonomi, geografi, sosiologi, sejarah, hukum, ilmu politik, dan budaya.

Berdasarkan hasil observasi yang dilakukan pada hari Sabtu tanggal 17 November 2018, guru menerangkan materi pembelajaran dengan sederhana, yaitu siswa men-dengarkan ceramah guru dan siswa menyimak materi yang ada di LKS. Media pembelajaran yang digunakan sudah menggunakan media elek-tronik sebagai media pendukung dalam pembelajaran, namun hanya sebatas gambar dan belum maksimal dalam pemanfaatan media elektronik yang ada. Selain observasi, peneliti juga melakukan wawancara kepada guru kelas IV SD Negeri 4 Kutosari. Menurut guru kelas IV SD Negeri 4 Kutosari, materi IPS tergolong materi yang sulit karena muatan materi dalam pembelajaran IPS didominasi dengan materi hafalan.

Berdasarkan data hasil Penilaian Tengah Semester (PTS) menunjukkan bahwa tingkat pe-mahaman siswa terhadap mata pelajaran IPS masih rendah yakni belum mencapai Kriteria Ketuntasan Minimal (KKM). KKM yang di-tetapkan untuk mata pelajaran IPS adalah 75. Dari data yang diperoleh untuk kelas IV yang terdiri dari 43 siswa hanya 20 siswa atau sebesar $46,52 \%$ saja yang mendapatkan nilai di atas KKM 75 , sedangkan yang mendapat nilai di bawah KKM sebanyak 23 siswa atau sebesar $53,48 \%$. Dari data tersebut terlihat bahwa kondisi hasil belajar IPS tergolong rendah sehingga mem-butuhkan sebuah penanganan khusus yaitu sebuah pembelajaran yang bermakna, salah satuya dengan pe-nerapan pendekatan saintifik.

Berkenaan dengan pen-dekatan saintifik, Hosnan (2016: 34) berpendapat bahwa pendekatan saintifik adalah konsep pembelajaran yang dibuat agar peserta didik aktif membangun konsep, hukum atau prinsip yang dilakukan dengan beberapa tahapan yang meliputi: mengamati, merumuskan masalah, merumuskan hipotesis, mengumpul-kan data, menganalisis data, menarik kesimpulan, dan mengkomunikasikan. Sejalan dengan pendapat tersebut, Daryanto (2014: 51) men-jelaskan bahwa pendekatan saintifik adalah proses pembelajaran yang di-rancang sedemikian rupa agar siswa secara aktif mengkontruksi konsep, hukum, atau prinsip melalui tahapantahapan mengamati (untuk mengidentifikasi atau menemukan masalah), merumuskan masalah, mengajukan atau merumuskan hipotesis, mengumpulkan data dengan berbagai teknik, mengolah data, menarik kesimpulan, dan mengkomunikasikan konsep, hukum, atau prinsip yang "ditemukan".

Pendekatan saintifik perlu didukung dengan media lain, salah satunya yaitu media video. Media video merupakan media elektronik yang memberikan sebuah peng-alaman berupa gambar bergerak dan suara yang dapat ditangkap oleh alat indra siswa. Daryanto (2013: 87) menjelaskan bahwa media video adalah bahan ajar non cetak yang memiliki banyak informasi dengan menyajikan gambar bergerak disertai dengan suara dan secara langsung dapat sampai kehadapan siswa. Sementara itu, Asyhar (2011: 74) mengatakan, "media video me-rupakan rekaman gambar dan suara 
dalam kaset pita video ke dalam pita magnetik". Dalam peggunaannya media video juga tidak rumit dan membutuhkan banyak biaya yang besar. Guru dapat menayangkan sebuah video pembelajaran yang menarik untuk menambah semangat siswa dalam proses pembelajaran.

Pembelajaran terjadi jika ter-jalin suatu interaksi antara individu dengan lingkungan sekitar. Rusmono (2014: 6) menyatakan bahwa pem-belajaran merupakan sebuah upaya dalam menciptakan suatu kondisi bagi terciptanya suatu proses belajar yang memungkinkan siswa memperoleh pengalaman belajar yang memadai. Lebih lanjut, menurut Hamdani (2011: 23), pem-belajaran merupakan usaha sadar seorang tenaga pendidik dalam proses pembentukan kepribadian atau tingkah laku yang diharapkan dengan menyediakan lingkungan sebagai sumber belajar. Dari pendapat tersebut dapat disimpulkan bahwa pembelajaran adalah upaya dalam menciptakan suatu kondisi bagi terciptanya suatu proses belajar guna mencapai tujuan pembelajaran dalam proses pembentukan ke-pribadian atau tingkah laku dengan menye-diakan lingkungan sebagai stimulus yang memungkinkan ter-jadinya proses belajar.

Karakteristik IImu Penge-tahuan Sosial (IPS) adalah ke-terpaduan. Sapriya (2011: 7) me-nyatakan bahwa ciri khas atau karakteristik IPS adalah sifat terpadu (integrated) dari sejumlah mata pelajaran dengan tujuan agar mata pelajaran ini lebih bermakna bagi peserta didik sehinggga materi dalam IPS disesuaikan dengan lingkungan, karakteristik dan ke-butuhan dari peserta didik. Sejalan dengan pendapat Sapriya, Supardan (2015: 54) menyatakan bahwa karakteristik IPS yaitu membantu peserta didik dalam belajar untuk menggunakan berbagai ketrampilan, pengetahuan dan sikap yang akan mempersiapkan mereka menjadi warga negara yang bertanggung jawab sepanjang hidup mereka. Berdasarkan kedua pendapat tersebut dapat disimpulkan bahwa karakter-istik dari pembelajaran IPS yaitu keterpaduan dari sejumlah mata pelajaran sehingga pembelajaran IPS lebih bermakna yang disesuaikan dengan kerakteristik dan kebutuhan peserta didik untuk mempersiapkan mereka menjadi warga negara yang bertanggung jawab.

Berdasarkan uraian di atas, peneliti tertarik untuk melakukan penelitian tindakan kelas dengan judul "Penerapan Pendekatan Saintifik dengan Media Video dalam Peningkatan Pembelajaran IPS Tema Indahnya Keragaman di Negeriku pada siswa kelas IV SD Negeri 4 Kutosari Tahun Ajaran 2018/2019".

\section{METODE}

Penelitian tindakan kelas ini dilaksanakan di SD Negeri 4 Kutosari. yang berlokasi di di Jalan Pahlawan No 207, Kabupaten Kebumen. Subjek penelitian tindakan kelas ini adalah siswa kelas IV SD Negeri 4 Kutosari. Jumlah siswa kelas IV adalah 43 siswa terdiri dari 20 siswa laki-laki dan 23 siswa perempuan. Jenis data pada penelitian tindakan kelas ini terdiri dari dua macam, yaitu data kualitatif dan data kuantitatif. Data kuantitatif berupa hasil observasi guru, hasil observasi siswa, hasil penilaian proses siswa, dan hasil belajar siswa. Sedangkan data kualitatif berupa hasil wawancara terhadap guru dan siswa melalui penerapan pendekatan saintifik dengan media video dalam peningkatan pembelajaran IPS.

Teknik pengumpulan data menggunakan teknik tes dan teknik non tes (observasi, wawancara dan dokumentasi). Dalam penelitian ini peneliti menggunakan teknik triangulasi, yaitu triangulasi sumber dan triangulasi teknik. "Triangulasi sumber berarti, untuk mendapatkan data dari sumber yang berbeda-beda dengan teknik yang sama" (Sugiyono, 2016: 330). Sedangkan triangulasi teknik digunakan untuk menjaga kevalidan data. Triangulasi teknik dilakukan untuk menguji kredibilitas data dengan cara me-ngecek data kepada sumber yang sama dengan teknik yang berbeda. Bentuk analisis data dalam penelitian ini menggunakan model Miles dan Huberman (Sugiyono, 
2016: 337-345) yang meliputi tiga alur yaitu reduksi data, penyajian data, dan kesimpulan.

Indikator kinerja penelitian ini adalah peningkatan pembelajaran IPS Tema Indahnya Keragaman di Negeriku dengan target $85 \%$. Prosedur penelitian yang digunakan sesuai dengan yang dikemukakan oleh Kemmis dan MC. Taggart (Arikunto, 2014: 137), yaitu: perencanaan, pelaksanaan, observasi, dan refleksi tindakan yang dapat dijadikan rencana tindakan se-lanjutnya.

HASIL DAN PEMBAHASAN

Kegiatan penelitian ini dilaksanakan dalam tiga siklus. Langkah pembelajarnnya yaitu: (1) pemilihan topik, (2) perencanaan kerja sama, (3) implementasi atau investigasi, (4) analisis dan sintesis, (5) presentasi hasil akhir, (6) evaluasi. Hasil observasi siswa dan guru pada penerapan pendekatan saintfik dengan media video dari siklus I sampai III selalu mengalami peningkatan dan telah mencapai indikator penelitian $85 \%$. Begitu pula dengan ketuntasan proses dan hasil belajar siswa.

Tabel 1. Hasil Observasi dan Wawancara Penerapan Pendekatan Saintifik Dengan Media Video

\begin{tabular}{lllll}
\hline Siklus & Observasi & & Wawancara & \\
& $\begin{array}{l}\text { Guru } \\
(\%)\end{array}$ & $\begin{array}{l}\text { Siswa } \\
(\%)\end{array}$ & $\begin{array}{l}\text { Guru } \\
(\%)\end{array}$ & $\begin{array}{l}\text { Siswa } \\
(\%)\end{array}$ \\
\hline I & 70,61 & 68,39 & 68,33 & 63,67 \\
II & 79,86 & 80,36 & 82,67 & 78,33 \\
III & 90,75 & 89,92 & 92,17 & 90,50 \\
\hline
\end{tabular}

Tabel 2. Ketuntasan Penilaian Proses dan Hasil Belajar Siswa

\begin{tabular}{lll}
\hline \multirow{2}{*}{ Siklus } & \begin{tabular}{l} 
Penilaian \\
\cline { 2 - 3 }
\end{tabular} & $\begin{array}{l}\text { Proses } \\
(\%)\end{array}$ \\
\hline I & 65,11 & $\begin{array}{l}\text { Hasil } \\
(\%)\end{array}$ \\
II & 82,55 & 63,96 \\
III & 96,51 & 83,73 \\
\hline
\end{tabular}

Berdasarkan hasil observasi dan wawancara terhadap guru dan siswa serta diperkuat dengan meningkatnya hasil penilaian proses dan hasil belajar maka penelitian tindakan kelas melalui penerapan pendekatan saintifik dengan media video sudah dilaksanakan dengan baik dan mencapai indikator kinerja penelitian $85 \%$. Maka dari itu penerapan pendekatan saintifik dengan media video terbukti dapat meningkatkan pembelajaran IPS tema Indahnya Keragaman di Negeriku pada Siswa Kelas IV SD Negeri 4 Kutosari Tahun Ajaran 2018/2019.

Peningkatan pembelajaran dari siklus I hingga siklus III tersebut sesuai dengan penelitian yang dilakukan oleh Palupi, Suhartono, dan Susiani (2017: 161) yang menunjukkan penggunaan model pembelajaran kooperatif tipe group investigation dengan media video dapat meningkatkan pembelajaran IPS tentang kegiatan ekonomi. 


\section{SIMPULAN}

Penerapan pendekatan saintifik dengan media video dalam peningkatan pembelajaran IPS Tema Indahnya Keragaman di Negeriku pada siswa kelas IV SD Negeri 4 Kutosari tahun ajaran 2018/2019 dilaksanakan melalui lima langkah yaitu: (a) mengamati video, (b) menanya berdasarkan video, (c) mengumpulkan informasi berdasarkan video, (d) menalar, dan (e) mengkomunikasikan. Peningkatan pembelajaran ini dibuktikan dengan hasil observasi dan wawancara terhadap guru dan siswa serta hasil penilaian proses dan hasil belajar siswa pada tiap siklusnya yang mengalami peningkatan dan sudah mencapai indikator kinerja penelitian $85 \%$ pada siklus III.

\section{DAFTAR PUSTAKA}

Arikunto, S. (2014). Prosedur Penelitian Suatu Pendekatan Praktik. Jakarta: Rineka Cipta.

Asyhar, R. (2011). Kreatif Pengembangan Media Pembelajaran. Jakarta: Gaung Persada Press.

Daryanto. (2013). Media Pembelajaran. Yogyakarta: Gava Media.

Daryanto. (2014). Pendekatan Pembelajaran Saintifik. Kurikulum 2013. Yogyakarta: Gava Media.

Hamdani. (2011). Strategi Belajar Mengajar. Bandung: CV Pustaka Setia.

Hosnan. (2016). Pendekatan Saintifik dan Kontekstual dalam Pembelajaran Abad 21. Bogor: Ghalia Indonesia.

Palupi, B.S., Suhartono., \& Susiansi, T.S. (2017). Peningkatan Pembelajaran IPS Tentang Kegiatan Ekonomi Melalui Model Pembelajaran Kooperatif Tipe Group Investigation dengan Media Video di Kelas IV SD. Kalam Cendekia, 5 (2.1), 157-161.

Rusmono. (2014). Strategi Pembelajaran dengan Problem Based Learning Itu Perlu. Bogor: Ghalia Indonesia.

Sagala, S. (2013). Konsep dan Makna Pembelajaran. Bandung: Alfabeta.

Sapriya. (2014). Pendidikan IPS Konsep dan Pembelajaran. Bandung: PT Remaja Rosdakarya.

Sugiyono. (2016). Metode Penelitian Pendidikan (Pendekatan Kuantitatif, Kualitatif, dan $R \& D)$. Bandung: Alfabeta.

Supardan. (2015). Pembelajaran Ilmu Pengetahuan Sosial Perspektif Filosofi dan Kurikulum. Jakarta: Bumi Aksara.

Susanto, A. (2013). Teori Belajar dan Pembelajaran di Sekolah Dasar. Jakarta: Kencana. 